\title{
Religious policy of the Song dynasty emperors
}

\author{
Xu Xinghua \\ (Journal editorial department, Tonghua normal university, Jilin Tonghua 134002)
}

Key words: Song Dynasty emperor; religious policy; monks’ management

\begin{abstract}
Learning the experience and lessons from two aspects of advocating and destroy the law in the history, the two Song Dynasty emperors started with politics, economy and monks management with a calm and objective attitude, and implemented the religious policies for fostering and restricting, guiding and utilizing, making developments of the two Song religion tend to smooth and harmonious.

The relationship, between the religion and regime during the two Song periods, basically was the harmonious and stable. By summarizing experience and lessons from two aspects of advocating and destroy the law in the history, the governors recognized that destroying the laws by force was not desirable, then they complied with the situation and made the best attitude to improve the occasion, and implemented the religious policies for fostering and restricting, guiding and utilizing, which allowed the moderate development of religion within a certain range, but never permitted its overexpansion or towards evil way to harm national centralized power.
\end{abstract}

\section{Political policy}

The rulers followed the trend and advocated the convergence of three religions

The convergence of three religions "emphasizes the inner consciousness of people to follow the feudal order, encourages people to improve their own personality from the internal rationality, and holds fast to moral integrity of the individual, translating the external constraint into inner consciousness". ${ }^{[1]}$ Taking a fancy to the availability of trend, rulers actively promoted the convergence of three religions, which can make the religions provide better service for the rule. Shin put forward, "Buddhism and Taoism can complement thoughts in that era. The set of three religions, its tenet is the same." ${ }^{[2]}$ He wrote the "Induction Theory" to expound its discussion. In August of Wellwishing three years (1019), Shin "Thirteen thousand and eighty-six people participated Taoism and Buddhism convention in the Tian'an temple"12], put the thought fusing Buddhist into operation. During the period of Renzong, the Yunmen minent monk, who had a good understanding of Confucianism, and Buddhism, had ever made "the Assistance Code", and emphatically advocated the convergence of three religions to assist the emperor, eventually combining Confucianism and Buddhism on the standpoint for consolidating current social systems. Renzong received the book and praised, "Command and deliver it to the office to the edit and put in order, showing the honor with praise". ${ }^{[5]}$ In the position for standing up for Buddhism and Taoism, Xiaozong wrote the "Original Theory of Tao" against Han Yu's essay "Original Tao", which criticized the basic idea of his essay tit-for-tat, and explicitly expounded the proposition for the combination of three religions. Xiaozong thought the basic ideas of three religions were completely consistent, as the reason for that some people believed that three religions had differences is "The ignorant people of descendants of three religions held their own ideas, and considered them the best". Actually, the difference of three religions is just "The thoughts of Buddhist predecessors had not excellent performances just for self-cultivation, while Confucius views were used to control the world, and they had different measures." On the issue" how to remove the confusion", to treat the three religions properly, he put forward "cultivating one's mind with Buddhist, keeping in good health with Taoism, ruling the world with Confucianism can also be best. Only the saints can do it all." ${ }^{[4]}$ Xiaozong "Original Tao" made a new play for the combination of three religions, especially the conclusion that" cultivating one's mind with Buddhist, keeping in good health with Taoism, 
ruling the world with Confucianism" is even more far-reaching.

The imperial power is greater than the magisterium

"Religion, what governs the human mind, should have been the most free and independent, out of control and power of others and left alone transcendentally." ${ }^{[5]}$ However, in Chinese feudal society, the emperor held the supreme political power absolutely, any religion, any ideology can only serve for the autocratic imperial power and must never fight against or above imperial power. Magisterium is only part of the temporal power, even though the religions were flourishing, they were completely enlisted under the regime, and what can illuminate the square world was only the power of regime, rather than the other.

When the emperor Taizong went to the xiangguo temple to burn incense and asked to worship or not, Zanning said unexpectedly: "The Buddha at present do not worship that in the past." ${ }^{[6]}$ He also proposed "Buddhist doctrine was formulated according to the law". "Baizhang Regulations" also put celebrate worship Kings "ZhuLi Section" for praising and adoring the emperor and "Baoen Section" before Baoben Section" for enshrining the Buddha master, the monks had to go to the temple and ode to course every day. The stele carved in the southern song dynasty "Shakya Shelley pagoda Jinzhong Yingxian figure " was located in Small Fo Wan of Mount Baoding in the Dazu county, there were tributes on each side in addition to the Buddha figure: " wish the emperor noble and wise, more longevous than the wise" and "hope the nation stable, the people health without wars, the weather fine and the farm harvest".[7] It can be seen that in the heart of the Buddhists, the Dharma is far more significant than the Buddhism, the loyalty to emperor is far more important than worship for Buddha, and the imperial power is absolutely greater than the magisterium.

To combine his rule with the destiny and show that his kingship is to be awarded by the heaven, Song emperors began to gradually improve the status of jade emperor as the Lord of all gods, and integrated themselves with the Haotian god with national sacrifices, and their identities were from the "opposition" to the "on the office". As anthropologists think that "The common features of all religions are to extend to the relationship of human to the supernatural things and strength." ${ }^{[8]}$ The jade emperor is the deification and extension of Chinese imperial power in the world of the other shore, is the projection of Confucian authority in the Taoist belief world.

Magisterium can get the balanced development by the attachment to the imperial power, once the conflict against the imperial power happened, the imperial rulers would suppress them, even had on the ruthless repression. In Song dynasty, religious activities without the official recognition always appeared on the official banning strictly list. Such as printing scriptures privately, in Chongning third years (1104) the states were commanded to capture and burn printed privately "Doomsday Buddha Sutra", and in Xuanhe second years (1120) the abstinence halls were commanded to be broken down and burn the privately essays "Qisi Sutra", "Certification Sutra", "Prince Sutra" and "Parents Sutra", etc.; Strange faith behaviors, for example, to prohibit refining the arm and burning the head, cutting the body and burning the finger, or sacrifice oneself to jump off the cliff and other means, which were on the grounds that "Damaging the body is harmful to the public education. Moreover, it is barbarian way, how can the Chinese people to emulate it" ${ }^{\text {[9] }}$. Such as private gatherings, especially "gathering at night and leaving before dawn to pass on and learn the demon method", were the most common social problems reported to the imperial court by officers. In Kaibao eighth year (975), Taizu banned initiation rites, the amphibious fast ceremonies and night gathering of young people and other kinds of activities to prevent mob. In Daguan second year (1108), Xinyang army played please to ban "gathering at night and leaving before dawn to pass on and learn the demon method and social fair of some organizations " ${ }^{[9]}$. "Due to violating the generally recognized schedule rules, secretly passing on and teaching beliefs outside of political ideology, they were quite terrible things for power owners. In the official political memory, these unusual activities and secret beliefs were easy to lead to the collapse of order, so that the prohibition for this kind of activity was always quite strict." ${ }^{[10]}$ Especially the suppression for manichaeism and other missions, also involved almost all of the pagan religions including the religion that might come from the foreign civilization. 


\section{Economic policy}

Identification cards of monks

The generation of the identification cards of monks is based on the need for strict control of religions by the imperial court. In the early Northern Song Dynasty, the cards issuance only symbolically levied a small fee, but since the mid-Northern Song Dynasty, Song Dynasty increased redundancy of soldiers and officials, and financial support became increasingly serious, then Jingdie became the regulator in economic field. People pointed out that: "In order to alleviate the state expenditure, the State sold cards of monks and title of nobility." [9] The court sometimes used the cards for young crops capital, sometimes for trade capital to control prices and stabilize the market; sometimes for relief purposes for flood victims; sometimes used Jingdie to purport military, such as Ningzong Jiading eleventh year (1218) " Supporting Sichuan military with cards of monks" [11]; While sometimes utilized the cards help to reform the monetary system, such as the Southern Song Guangzong "Spend the two hundred monks cards to close Huaidong iron money." With the increase of more widely application of the identification cards of monks, the fee was also increasing year by year. In the early Shaoxing Dynasty, the official price of each card was one hundred and twenty strings, which increased to five hundred strings in Shaoxing thirty-first year (1161), [9] and to seven hundred strings in Xiaozong Chunxi fourteenth year (1187). ${ }^{[9]}$ The local government received the cards with null name from the chancery to pay for labor costs, resulting in circulation of the cards of monks same as currency in the market, which became a great spectacle in China's religious history and financial history.

The sale of purple clothes title

Rewarding purple clothes title was reward for the monks active in the imperial court or knowledgeable men from the emperors, to draw them to serve for their own rules, so the early song dynasty government controlled them strictly. Purple clothes, title card was engraved and printed with the yellow paper at the beginning, which turned to the thin silk when Yuanfeng and changed into the tough silk when Shaoxing. In Chunxi forth year (1177), in the Shu the purple clothes title cards were changed into the identification card, Xiaozong commanded to burn the old cards, and the false proof mark was added into the new card. ${ }^{[9]}$ But with the deterioration of government economy, purple clothes title began to sell as same as the identification. In Xining forth year (1071) "Give Hebei transport department five hundred monk cards, purple clothes and titles each two hundred and fifty" ${ }^{[9]}$, which were used to build up the river. This purple clothes title also had the price, such as in November of Jianyan second year (1128), "the title with four words was sold for two hundred thousand." ${ }^{[12]}$ The southern song dynasty in the southeast had poor public finance to make ends meet, purple clothes title cards as securities were widely used to buy rice, military expense, yeast and steam again capital, and so on. According to the record, the Zhang Jun, Zhao Ding handled and sold ten thousand purple clothes and title. The frequent sale of purple clothes titles, making it lost the past glory.

Cancels "avoiding military service tax" and increase"corvee-exemption tax"

In the southern song dynasty, as the sale of purple clothes titles and the development of the temples, the increase in the number of monks, and the poor public finance, "the court had to attach importance to the relations between these phenomena and finance ", [13] it meant opening up financial resources and increasing tax objects. The Shaoxing fifteenth year (1145), the government signed a letter to ask for the "avoiding military service tax". "In the fifteenth year, all monks were commanded to begin to hand in tax, from ten thousands to one thousand and three hundred, all in nine levels, called free money. Who were more than 60 old years and disabled could avoid the tax." ${ }^{[12]}$ Among them "Law monks handed in five thousand, Buddhist monks and Taoist priest for two thousand, then the abbot, elders, mages, purple clothes, the governor were increasing to fifteen thousand of all nine levels." ${ }^{[14]}$ Some scholars made statistics, poll tax of Taoist priest was 5.13 times higher than that of the common people, that of the men with a mage title was 20.5 times. ${ }^{[15]}$ In addition to "leisure money", the government has charged "corvee-exemption tax". The Song Dynasty inherited the system of five generations, carried out the attendants law, "monks had no service". ${ }^{[16]}$ In Shenzong period, Wang anshi changed the attendants law into avoiding military 
service law, in which the people gave money in accordance with the amount of property, and the government hired people for service, called " avoiding military service tax", the original men without service gave" corvee-exemption tax", and temples also handed in half of the people. in the first month of the first year of Zhezong Yuanyou(1086), Sima Guang recalled service law, and the monks gave money as before corvee, charge of each state. ${ }^{[17]}$ Shaosheng repeated the offering service law, temples also remained in half of the people basically which have been used to until the song.

Strengthen the economic management of temples

Urban and rural development of handicraft industry and business had promoted the prosperity of the city, also strongly stimulated the contact of temples economic with secular society. Temples universally managed "immortality library", grinding mill, stores, warehouses, hotels, loan sharks and other commercial services, developed profitable business, so the income was very considerable, and the temples economy had fully shown the rules of manor economy at this time. Song followed temple field on tax policy, temple monastic lands levied both the spring and autumn taxes as folk-land. A few temples exempted from the two taxes, and must get the concession of emperor. Song dynasty surtaxes were many, and the temple should bear all of it in principle. With Taoism as example, Taoist smelted with of "age class". Since Yuanfeng years, if monastic boat wanted to pass GuanJin, it should "in accordance with the article hand in the tax dollars". ${ }^{9]}$ According to the report by tongbo Shanchong governor Jiang Yunchong in Qianao second year (1166): monastic and strongly borrowing items, apportioned the provisional duties, the move(sent taxes to the designated place, can accept money and avoid shift), refractive index change (temporary discount on some material), folding silks (discount on textiles), tea, salt and other tax items.

\section{Management policies for monks}

In Song dynasty, the management of religions, following Tang system, adopted the principle "The state owning religion should rule people with the religion, the state owning custom should rule people with the custom", and set up two sets of institutions for religions and customs managing specially religious affairs, whose real power were in the hands of customs officers. In order to prevent the bureaucrats, the emperor even assigned monks management power belonging to several governments. David bunch temple controlled the foreign monks, and "Prohibitions of Zhongdou Daoshi temple and records" [9]; Shrine of ministers were in charge of "states native places of Buddhist, monks, female taoist and children" [9]; Zhongshu or Menxia province were in charge of the number of national temples, abbot candidates and give the national big temples monks "purple" "title" and other things; Kaifeng governor of merits and virtues, responsible for the issuance of inspector cards and by-election of religious officers; Three departments and ministry of revenue managed the two taxes; The ministry of works were responsible for the "purple", "title," and cards production. The multiple departments, as it were, made the multiple management of the religions affairs, which was one of the features of song dynasty's religious policies.

The organizations set up by government for the monks to manage religious affairs were central and local forms. The centre set up left and right street Buddhist registry( Taoism registry), which had a monk record(Taoism record), chief monk, the meaning and other positions, all around the place, and the left were more superior. The higher both street monk records were above the monk recorded and on the left and right. ${ }^{[18]}$ The local set up Buddhist registry (Taoism registry) headed by the monks (Taoism). The section and teaching of religious officials varied from the time and things, summing up roughly royal filling, avoiding teaching, the state military interpolation, selection after try, and election by religious people five kinds. Only to take the selection after try as an example, its close degree could be equivalent to that of the imperial examination system. According to volume 47 of the "old five dynasties history", who wanted to apply for exams of monk officer, had forty Fala and more than twenty Xiaanju. It would set seven subjects' exams, and exam rooms required to be isolated, but also the names on the paper should be sealed with paste. Even if one passed the exam, he still did not have the actual duty. Actual duty would be endowed in the mean of assignment, namely the emperor, or province, state or military government ministers 
directly sent someone to somewhere to grasp the real power and dealt with concrete matters. As the selection and patronage of religious officers were in the hands of customs officers, the government firmly controlled the religious affairs.

\section{References}

[1] Ge Zhaoguang. Taoism and Chinese Culture [M] Shanghai: Shanghai People's Publishing House, 1987.

[2] Li Tao. Continued History As A Mirror Complications [M]. Shanghai: Shanghai Ancient Books Publishing House, 1986.

[3] Chen Shunyu. Tanjin Zoroastrianism Master Industry Record [M]. Shanghai: Shanghai Bookstore, 1986.

[4] Zhao Shen. The original theory [G] / /Chen Menglei. Integration of Ancient and Modern books. 494. Beijing: Zhonghua Book Company Photocopy.

[5] Fuzeyuji. Outline of Civilization Theory [M]. Shanghai: Commercial Press, 1997.

[6] Ouyang Xiu. Ouyang Xiu Complete Works [M]. Beijing: Zhonghua Book Company, 1986.

[7] Chongqing Dazu Stone Carving Art Museum, Dazu Stone Carving Art Institute of Sichuan Academy of Social Sciences. Small Fo Wan of Mount Baoding in the Dazu county "Shakya Shelley pagoda Jinzhong Yingxian figure" memorial [J]. Journal of Cultural Relics, 1994 (2): 40 and 41.

[8] P.M.Jixin. north morning compilation. Outline of Contemporary Cultural Anthropology [M]. Hangzhou: Zhejiang People's Publishing House, 1986.

[9] Xu Song, Draft of Song Huiyao[M]. Beijing: Zhonghua Book Company, 1957.

[10] Ge Zhaoguang. Chinese Thought History (volume 2) [M]. Shanghai: Fudan University Press, 2001.

[11] Tuo Tuo. History of Yuan [M]. Beijing: Zhonghua Book Company, 1977.

[12] Zhi Pan. EC Buddha Ji [M]. Nanjing: Photocopy According to the Edition of Jiangsu Guangling Ancient Engraving, 1992.

[13] Daoduaniangxiu. Poll Tax of Buddhism and Taoism in the Song Dynasty [G] // Mr Yamazaki Retired Official Commemoration of Oriental History Essays. 1967.

[14] BiYuan. Continued History As A Mirror [M]. Beijing: Zhong Hua Press, 1957.

[15] Ren Jiyu. Chinese Taoism History [M]. Beijing: China Social Sciences Publishing House, 2001.

[16] Wang Cheng. East Capital Biographical Sketch [M]. Nanjing: Jiangsu Guangling Ancient Engraving Agency Photocopying, 1990.

[17] sima guang. Family Heirloom Set (volume 49) [G] // Si Ku Quan Shu in Wen Yuan Ge, 1527.

[18] chang-dong liu. Theory on the Monk Officers System in Song Dynasty [J]. World Religious Studies, 2003 (3) : 52-53. 